\title{
Erratum to: Molecular phylogeny of the tropical lichen family Pyrenulaceae: contribution from dried herbarium specimens and FTA card samples
}

\author{
Cécile Gueidan $^{1,2} \cdot$ André Aptroot $^{3} \cdot$ Marcela Eugenia da Silva Cáceres $^{4}$. \\ Nguyen Quoc Binh ${ }^{5}$
}

Published online: 21 January 2016

(C) German Mycological Society and Springer-Verlag Berlin Heidelberg 2016

\section{Erratum to: Mycol Progress (2016) 15: 7}

DOI 10.1007/s11557-015-1154-8

The original publication unfortunately contained an error. The authors have just realised that the wrong collection number was used for the holotype in the description of the new species Lithothelium immersum. See below for the correct citation:

Typus: Brazil, Rondônia/Amazonas-border, Fazenda São Francisco off BR319, $30 \mathrm{~km} \mathrm{~N}$ of Porto Velho, 8'24'33" $\mathrm{S}, 63^{\circ} 58^{\prime} 56^{\prime \prime} \mathrm{W}$, alt. c. $100 \mathrm{~m}$, on tree bark in primary rain forest, 15 March 2012, M. Cáceres \& A. Aptroot 11919 (ISE - holotypus, ABL—isotypus) (Fig. 6).

The online version of the original article can be found at http://dx.doi.org/ 10.1007/s11557-015-1154-8.

Cécile Gueidan

Cecile.Gueidan@csiro.au

1 Department of Life Sciences, Natural History Museum, Cromwell Road, SW7 5BD London, UK

2 Present address: National Facilities and Collections, National Research Collections Australia, Australian National Herbarium CSIRO, P.O. Box 1600, Canberra, ACT 2601, Australia

3 ABL Herbarium, Gerrit van der Veenstraat 107, NL-3762 XK Soest, The Netherlands

4 Departamento de Biociências, Universidade Federal de Sergipe, CEP: 49500-000 Itabaiana, Sergipe, Brazil

5 Department of Biology, Vietnam Academy of Science and Technology, Vietnam National Museum of Nature, 18 Hoang Quoc Viet Street, Cau Giay, Hanoi, Vietnam 